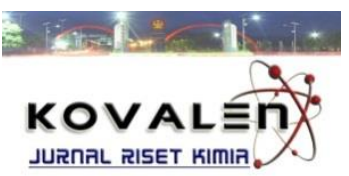

\title{
EKSTRAKSI DAN UJI STABILITAS BETASIANIN DALAM EKSTRAK BUAH KAKTUS (Opuntia elatior Mill.)
}

\section{[Extraction and Stability Test of Betacyanin in Cactus (Opuntia elatior Mill.) Extract]}

\author{
Patrisia Marcevin Rengku ${ }^{1}$, Ahmad Ridhay ${ }^{1 *}$, Prismawiryanti ${ }^{1}$ \\ ${ }^{1}$ Jurusan Kimia Fakultas MIPA, Universitas Tadulako \\ Jl. Soekarno Hatta Km.9, Kampus Bumi Tadulako Tondo Palu, Telp. 0451- 422611 \\ Diterima 2 April 2017, Disetujui 19 Juni 2017
}

\begin{abstract}
Research on extraction and stability test of betacyanin in cactus (Opuntia elatior Mill.) extract has been done. This study aimed is to determined the effect of solvent ratio (ethanol, a mixture of ethanol : water and water) on levels betacyanin cactus fruit extract. The extraction was done by maceration method for 72 hours on all variation solvent. The best results from treatment and betacyanin stability test to light and $\mathrm{pH}$. Betacyanin stability against of light testing is done with the exposure betacyanin cactus fruit extract under direct sunlight for 5 hours with a variety of storage containers, namely bottles brown and clear bottles. Betacyanin content analysis was done every 1 hour. Betacyanin stability against $\mathrm{pH}$ testing is

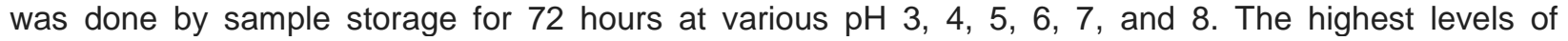
betacyanin using solvent water is $15.42 \mathrm{mg} / 100 \mathrm{~g}$. Betacyanin unstable on exposure to sunlight which betacyanin levels decreased by $47.35 \%$ on a brown bottle and $66.93 \%$ in clear bottles after 5 hours of storage. Betacyianin stable at pH 4, 5 and 6 with reduced levels of betacyanin by $15.82 \%, 14.25 \%$ and $15.71 \%$ respectively.
\end{abstract}

Keywords : Cactus (Opuntia elatior Mill.), Extraction, Betacyanin Stability

\begin{abstract}
ABSTRAK
Telah dilakukan penelitian tentang ekstraksi dan uji stabilitas ekstrak buah kaktus (Opuntia elatior Mill.). Penelitian ini bertujuan untuk mengetahui pengaruh variasi pelarut (etanol; campuran etanol : air; dan air) terhadap kadar betasianin dalam ekstrak buah kaktus. Ekstraksi dilakukan dengan metode maserasi selama 72 jam pada semua variasi pelarut. Hasil terbaik dari perlakuan di atas kemudian dilakukan pengujian stabilitas betasianin terhadap cahaya dan $\mathrm{pH}$. Pengujian stabilitas terhadap cahaya dilakukan dengan pemaparan betasianin ekstrak buah kaktus dibawah sinar matahari langsung selama 5 jam dengan variasi wadah penyimpan, yaitu botol cokelat dan botol bening. Analisis kadar betasianin dilakukan setiap 1 jam. Pengujian stabilitas betasianin terhadap $\mathrm{pH}$ dilakukan dengan cara penyimpanan sampel selama 72 jam dengan variasi $\mathrm{pH} 3,4,5,6.7$ dan 8. Kadar betasianin tertinggi diperloleh menggunakan pelarut air yaitu sebesar $15,42 \mathrm{mg} / 100 \mathrm{~g}$. Betasianin tidak stabil terhadap paparan cahaya matahari dimana kadar betasianin berkurang sebanyak $47,35 \%$ pada botol cokelat dan $66,93 \%$ pada botol bening setelah 5 jam penyimpanan. Betasianin stabil pada kondisi pH 4, 5 dan 6 dengan penurunan kadar betasianin masing-masing sebesar $15,82 \%, 14,25 \%$ dan $15,71 \%$.
\end{abstract}

Kata Kunci : Buah Kaktus (Opuntia elatior Mill.), Ekstraksi, Stabilitas Betasianin

*) Coresponding author: ahmadridhay@yahoo.co.id 


\section{LATAR BELAKANG}

Buah Kaktus (Opuntia elatior Mill.) diketahui mengandung betasianin sebesar 47,10 mg/100 ml (Chauhan et al., 2013). Betasianin adalah zat warna alami yang berwarna merah. Zat warna betasianin ini bersifat polar sehingga larut dalam pelarut polar (Soewandi dalam Khuluk et al., 2007). Ekstrak betasianin dimanfaatkan sebagai pewarna alami. Betasianin dapat diekstraksi menggunakan pelarut air, etanol, dan metanol, tetapi penggunaan pelarut air dalam proses pemekatan perlu diperhatikan karena penggunaan panas dapat mengakibatkan kerusakan senyawa betasianin sebab titik didih air cukup tinggi $\left(100^{\circ} \mathrm{C}\right)$. Betasianin sangat tidak stabil pada pemanasan suhu $70^{\circ}$ dan $80^{\circ} \mathrm{C}$ (Havlikova dalam Khuluk et al., 2007). (Azeredo, 2006).

Faktor-faktor yang mempengaruhi kestabilan betasianin adalah $\mathrm{pH}$, suhu, cahaya matahari, sinar lampu dan oksidator. Sutrisno dalam Khuluk et al., (2007), menyatakan bahwa suhu tinggi dan waktu pemanasan yang lama dapat menyebabkan terjadinya dekomposisi dan perubahan struktur pigmen betasianin sehingga terjadi pemucatan. Berdasarkan hal tersebut, maka diharapkan penentuan kondisi $\mathrm{pH}$ betasianin yang tepat dapat mengurangi tingkat kerusakan betasianin selama masa penyimpanan serta pengaruh paparan cahaya terhadap pengurangan kadar betasianin.

\section{METODE PENELITIAN}

\section{Bahan dan Peralatan}

Bahan yang digunakan dalam penelitian ini adalah buah kaktus (Opuntia elatior Mill.), akuades, etanol 95\%, $\mathrm{HCl}$, $\mathrm{NaOH}$, dan kertas saring.

Peralatan yang digunakan adalah Spektrofotometer UV-Vis (Parkin Elmer) dan alat gelas yang umum digunakan dalam laboratorium.

\section{Rancangan Penelitian}

Penelitian ini menggunakan Rancangan Acak Lengkap (RAL) yang disusun dengan variasi pelarut (etanol; campuran etanol : air (1:1); dan air). Hasil terbaik kemudian dilakukan uji lanjutan dengan pengujian kestabilan betasianin terhadap paparan cahaya matahari dan $\mathrm{pH}$.

\section{Prosedur Penelitian}

Proses Ekstraksi Betasianin dari Buah Kaktus (Modifikasi metode Khuluk et al., 2007)

Proses ekstraksi dilakukan dengan menggunakan metode maserasi yaitu sebanyak $100 \mathrm{~g}$ jus buah kaktus (Opuntia elatior Mill.) dimasukan ke dalam bejana maserasi kemudian ditambahkan pelarut etanol, campuran etanol : air (1:1) dan pelarut air masing-masing sebanyak $250 \mathrm{ml}$ kemudian dilakukan perendaman selama 72 jam yang diletakan dalam wadah tertutup pada suhu ruang. Setelah 72 jam masingmasing sampel kemudian disaring menggunakan penyaring vakum. Filtrat 
yang diperoleh dipekatkan menggunakan rotari vakum evaporator untuk memisahkan pelarut dari ekstrak.

\section{Uji Kualitatif Betasianin dalam Ekstrak Buah Kaktus}

Betasianin ditambahkan dengan $\mathrm{NaOH} 2 \mathrm{M}$ tetes demi tetes dan diamati perubahan warna. Uji positif ditandai dengan adanya perubahan warna larutan menjadi warna kuning. Pengujian dilakukan sebanyak 3 kali. Kemudian dilanjutkan dengan analisis menggunakan spektroskopi Fourier Transform Infrared (FTIR) untuk mengidentifikasi senyawa betasianin dalam ekstrak buah kaktus (Opuntia elatior Mill.).

\section{Uji Kuantitatif Betasianin dalam Ekstrak Buah Kaktus}

Satu $\mathrm{ml}$ betasianin ekstrak buah kaktus dilarutkan dalam pelarut buffer fosfat $\mathrm{pH} 5$ hingga volume $100 \mathrm{ml}$ kemudian diukur serapannya menggunakan spketrofotometer UV-Vis pada panjang gelombang maksimum yakni pada panjang gelombang $531 \mathrm{~nm}$. Selanjutnya dilakukan penentuan kadar betasianin menggunakan persamaan (Lim et al., 2011) :

Kadar betasianin $(\mathrm{mg} / 100 \mathrm{~g})=\frac{\mathrm{A} \times \mathrm{MW} \times \mathrm{V} \times \mathrm{Df}}{\varepsilon \times \mathrm{L} \times \mathrm{W}} \times 100$ Keterangan :

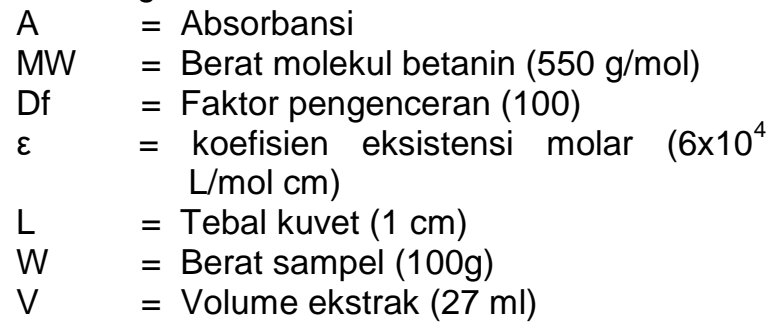

Uji Stabilitas Betasianin (Modifikasi metode Reshmi et al., 2012)

\section{a. Pengaruh paparan cahaya matahari.}

Pada perlakuan ini betasianin ekstrak buah kaktus yang digunakan merupakan hasil ekstrak menggunakan pelarut air. Betasianin ekstrak buah kaktus dimasukkan dalam botol I (botol kaca bening) dan dalam botol II (Botol kaca berwarna cokelat) masing-masing $6 \mathrm{ml}$. Kedua sampel diletakan pada luar ruangan yang terpapar sinar matahari secara langsung. Paparan terhadap cahaya matahari berlangsung selama 5 jam. Setiap 1 jam dilakukan analisis sampel menggunakan spektrofotometer UV-Vis sampai 5 jam. Perlakuan dilakukan sebanyak 2 kali.

\section{b. Pengaruh pH selama penyimpanan.}

Ekstrak betasianin dibuat dalam kondisi $\mathrm{pH}$ yang berbeda-beda yakni $\mathrm{pH}$ 3,4,5,6,7 dan 8 dengan menambahkan $\mathrm{HCl}$ $0,1 \mathrm{M}$ dan $\mathrm{NaOH} \quad 0,1 \mathrm{M}$ kemudian ditambahkan larutan buffer sitrat - fospat. Sampel disimpan dalam botol kedap udara serta kedap cahaya dengan waktu penyimpanan selama 72 jam pada suhu ruang, $\mathrm{pH}$ sampel diukur menggunakan $\mathrm{pH}$ meter sebelum dan sesudah masa penyimpanan untuk memastikan tidak adanya perubahan $\mathrm{pH}$ pada sampel. Selanjutnya dilakukan analisi menggunakan spektrofotometer UV-Vis. 
HASIL DAN PEMBAHASAN

\section{Kadar betasianin dalam Ekstrak Buah Kaktus (Opuntia elatior Mill.)}

Kadar betasianin dalam ekstrak buah kaktus disajikan pada gambar berikut ini :

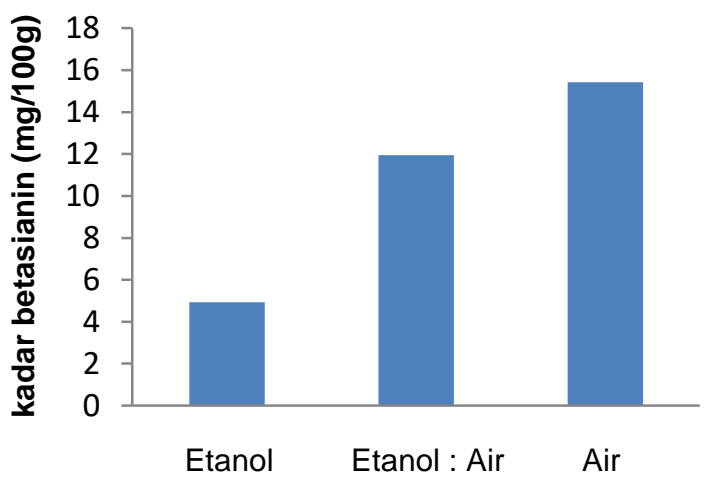

Pelarut

Gambar 1. Pengaruh jenis pelarut terhadap kadar betasianin

Ekstrak yang diperoleh menunjukan adanya perbedaan yang signifikan antara kadar total betasianin yang menggunakan pelarut air, etanol serta pelarut campuran etanol : air. Kadar betasianin tertinggi diperoleh menggunakan pelarut air sebesar $15,43 \mathrm{mg} / 100 \mathrm{~g}$ (Gamba 1). Hal ini sesuai dengan teori yang mengatakan bahwa betasianin merupakan zat warna yang bersifat polar sehingga dapat larut dalam pelarut polar (Soewand dalam Khuluk et al., 2007). Hasil penelitian yang dilakukan oleh Chauhan et al., (2013) menyatakan bahwa buah kaktus (Opuntia elatior Mill.) mengandung betasianin sebanyak 47,10 $\mathrm{mg} / 100 \mathrm{ml}$. Kadar betasianin total yang diperoleh dalam penelitian ini menunjukan kadar total betasianin dalam buah kaktus (Opuntia elatior Mill.) sebesar 15,43 $\mathrm{mg} / 100 \mathrm{~g}$. Hasil yang diperoleh sedikit berbeda. Hal ini dapat terjadi karena kadar betasianin dalam suatu tumbuhan dipengaruhi olh beberapa faktor. Menurut Rukmana dan Yunarsih (1998) mencatat bahwa kadar betasianin dalam suatu tanaman dapat dipengaruhi beberapa faktor diantaranya suhu (temperatur), kelembapan udara, curah hujan, sinar matahari dan angin.

\section{Hasil Uji Kualitatif Betasianin}

Ekstrak buah kaktus (Opuntia elatior Mill.) positif mengandung betasianin yang ditandai dengan adanya perubahan warna menjadi warna kuning dengan penambahan $\mathrm{NaOH} 2 \mathrm{M}$. Hal ini sesuai dengan teori yang menyatakan bahwa penambahan basa $(\mathrm{NaOH})$ pada betasianin menyebabkan perubahan warna menjadi warna kuning (Harborne, 1987). Menurut Vargas et al., (2010) penurunan $\mathrm{pH}$ akan menyebabkan perubahan pigmen merah menjadi warna ungu, sedangkan kenaikan $\mathrm{pH}$ menyebabkan perubahan menjadi kuning kecokelatan.

Hasil analisis menggunakan spektroskopi Fourier Transform Infrared (FTIR) disajikan dalam gambar berikut ini : 


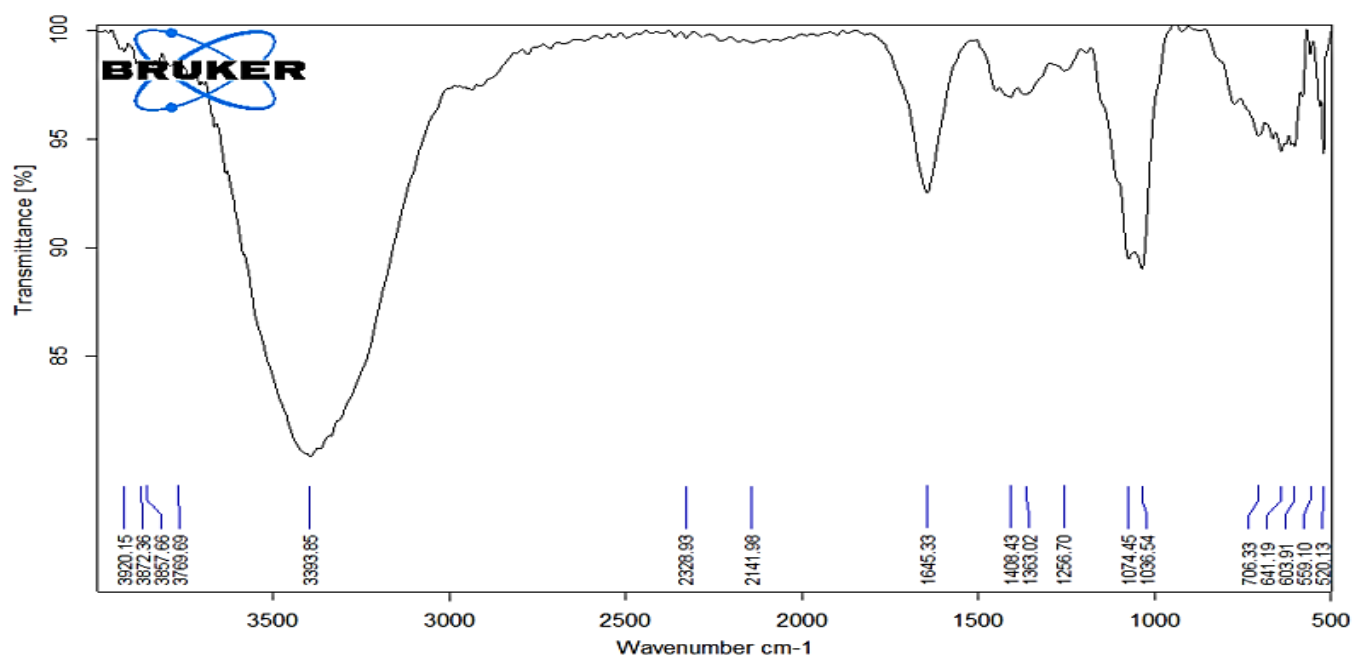

Gambar 2. Spektrum FTIR senyawa betasianin dalam ekstrak buah kaktus

Menurut hasil identifikasi menggunakan spektroskopi FTIR (Gambar 2) menunjukan adanya interaksi molekul dengan radiasi elektromagnetik yang berada pada panjang gelombang 4000 $500 \mathrm{~cm}^{-1}$. Pada daerah frekuensi $3393 \mathrm{~cm}^{-1}$ merupakan gugus $\mathrm{OH}$ dengan vibrasi ulur. Pada daerah ini biasanya juga terdapat gugus NH. Karena menurut Hargis (1988), pada daerah bilangan gelombang 3700$2700 \mathrm{~cm}^{-1}$ merupakan daerah serapan hydrogen. Field et al., (2008) menyatakan bahwa nilai serapan $\mathrm{O}-\mathrm{H}$ berada pada bilangan gelombang antara $3600-3200 \mathrm{~cm}^{-1}$. Ikatan hydrogen menyebabkan puncak melebar dan terjadi pergeseran ke arah bilangan gelombang yang lebih pendek. Pada bilangan gelombang 1408,43 $\mathrm{cm}^{-1}$ merupakan daerah serapan $\mathrm{C}-\mathrm{H}$ alifatik, $1645 \mathrm{~cm}^{-1}$ merupakan $\mathrm{C}=\mathrm{O}$ dengan vibrasi ulur dari asam karboksilat, 1363,02 $\mathrm{cm}^{-1}$ merupakan $\mathrm{C}=\mathrm{N}$ vibrasi ulur, $1074 \mathrm{~cm}^{-1}$ merupakan ikatan C-O-C dengan vibrasi ulur simetri, $1036 \mathrm{~cm}^{-1}$ merupakan ikatan CO-C dengan vibrasi ulur asimetri, 706,33 $\mathrm{cm}^{-1}$ merupakan $\mathrm{C}-\mathrm{H}$ yang terdapat dalam cincin benzen. Hal ini sesuai dengan teori yang mengatakan bahwa daerah serapan $\mathrm{C}-\mathrm{H}$ cincin benzen berada pada bilangan gelombang antara 870-675 $\mathrm{cm}^{-1}$. Berdasarkan hasil indentifikasi spectrum tersebut dapat diasumsikan bahwa dalam ekstrak buah kaktus (Opuntia elatior Mill.) mengandung betasianin.

\section{Hasil Uji Kuantitatif Betasianin}

Uji kuantitatif ekstrak buah kaktus dilakukan dengan analisis menggunakan spektrofotometer UV-Vis diperoleh nilai serapan maksimum pada panjang gelombang $531 \mathrm{~nm}$. Menurut hasil penelitian yang dilakukan oleh Chauhan et al., (2013), betasianin yang berasal dari tanaman yang sama memiliki nilai serapan maksimum pada panjang gelombang 538 
nm. Selain itu, Cai et al., (1998) mencatat bahwa nilai serapan maksimum ekstrak betasianin yang berasal dari tanaman bit (Beta vulgaris L.) memiliki nilai serapan maksimum pada panjang gelombang 537 nm. Hal ini sesuai dengan teori yang menyatakan bahwa senyawa betalain menyerap cahaya dengan kuat pada panjang gelombang antara 532-554 nm (Harborne, 1987) yang merupakan serapan warna hijau sehingga warna yang tampak adalah ungu kemerahan (warna komplementer) (Tiley dalam Moss, 2002). Kadar betasianin yang diperoleh dengan menggunakan pelarut etanol, campuran etanol : air dan pelarut air masing-masing sebesar 4,94 mg/100g; 11,95 mg/100g; dan $15,42 \mathrm{mg} / 100 \mathrm{~g}$.

\section{Hasil Uji Stabilitas Betasianin Terhadap Paparan Cahaya Matahari}

Perubahan kadar betasianin selama masa penyimpanan ditunjukan dalam gambar berikut ini :

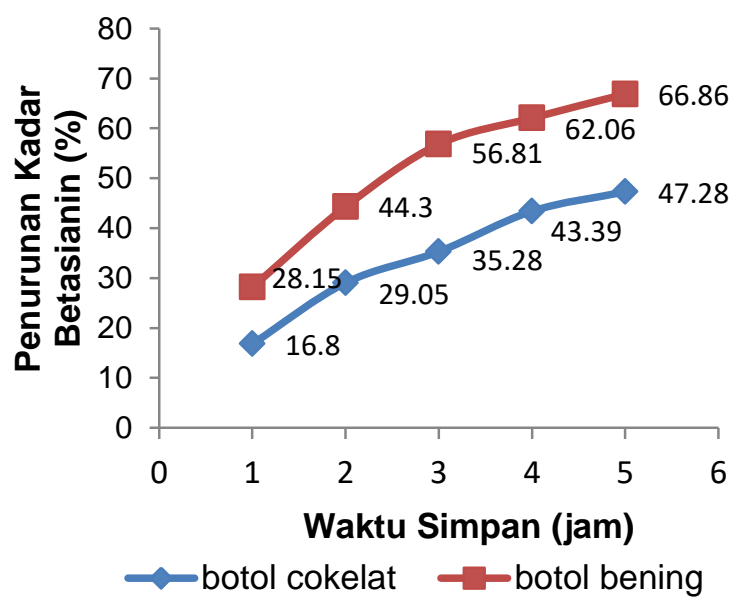

Gambar 3. Grafik Penurunan kadar betasianin selama penyimpanan
Hasil yang diperoleh menunjukan adanya pengaruh pada kadar betasianin terhadap penyinaran cahaya matahari selama 5 jam pemaparan (Gambar 3). Hasil analisis yang dilakukan pada setiap 1jam, 2 jam, 3 jam, 4 jam dan 5 jam waktu paparan menunjukkan adanya penurunan kadar betasianin pada botol kaca berwarna cokelat yaitu masing - masing sebesar $16,92 \%$; 29,09\%; 35,31\%; 43,47\%; dan $47,35 \%$. Sedangkan penurunan kadar betasianin pada botol bening masing masing sebesar 28,23\%; 44,37\%; 56,85\%; $62,09 \%$; dan 66,93\%.

Berdasarkan data tersebut dapat dilihat bahwa sampel yang disimpan dalam botol kaca berwarna cokelat mengalami penurunan kadar betasianin lebih sedikit dibandingkan sampel yang di simpan dalam botol kaca bening (transparan) selama 5 jam pemaparan. Hal ini disebabkan oleh botol kaca yang berwarna cokelat cenderung menghalangi sinar ultraviolet yang beinteraksi dengan betasianin. Sehingga tingkat kerusakan betasianin berkurang di bandingkan pada botol kaca yang bening. Sehingga dapat disimpulkan bahwa betasianin tidak stabil terhadap paparan cahaya matahari. Hal ini sesuai dengan teori yang menyatakan bahwa sinar UV maupun sinar tampak mampu mengeksitasi electron $\pi$ dari gugus kromofor ke tingkat energi yang lebih tinggi $\left(\pi^{*}\right) \quad$ karena adanya energi yang 
dipancarkan oleh sinar tersebut (Azeredo, 2006). Selain itu, Attoe dan von Elbe (1981) mengatakan bahwa oksigen berperan penting sebagai fotokatalis dalam perusakan pigmen betalain. Dengan demikian energi yang dipancarkan oleh cahaya matahari dapat merusak struktur betalain (dalam hal ini betanin) dan terurai menjadi asam betalamat dan siklo DOPA.

\section{Hasil Uji Stabilitas Betasianin Terhadap pH Selama Penyimpanan}

Hasil yang diperoleh setelah 3 hari penyimpanan menunjukkan adanya penurunan kadar betasianin pada masingmasing $\mathrm{pH}$. Penurunan kadar betasianin disajikan dalam grafik berikut ini :

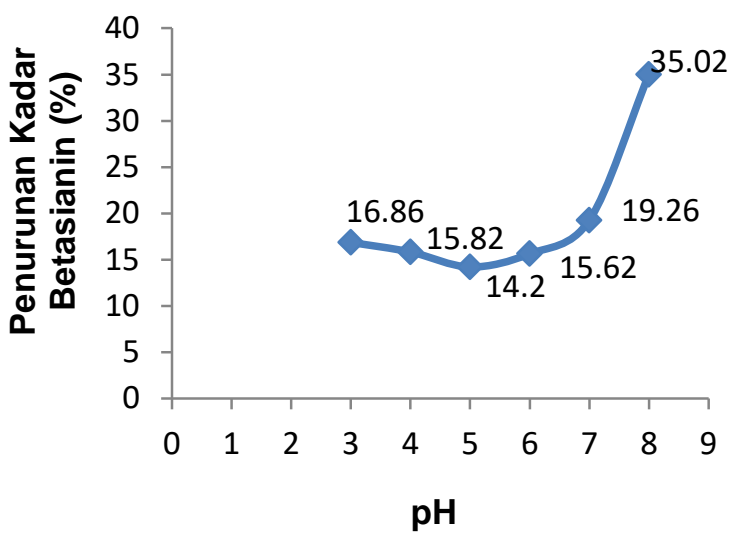

Gambar 4. Grafik penurunan kadar betasianin selama penyimpanan

Data tersebut menunjukkan adanya penurunan kadar betasianin terhadap $\mathrm{pH}$ sampel selama masa penyimpanan. Hal ini ditandai dengan adanya perubahan kadar ekstrak betasianin yang berbeda-beda pada masing-masing $\mathrm{pH}$. Penurunan kadar betasianin pada setiap sampel yang disimpan pada kondisi $\mathrm{pH}$ 3, 4, 5, 6, 7 dan 8 yaitu masing - masing sebesar 16,95\%; $15,82 \%$; 14,255; 15,71\%; 19,27\%; dan $35,11 \%$ (Gambar 4). Jackman dan Smith (1996) mencatat bahwa betalain relatif stabil diatas $\mathrm{pH}$ antara 3 sampai 7 dengan mempertimbangkan pemanfaatannya terhadap tingkat keasaman makanan. Dari hasil yang diperoleh dapat dikatakan bahwa betasianin cenderung stabil pada kondisi $\mathrm{pH}$ 4,5 dan 6. Pada kondisi $\mathrm{pH}$ tersebut penurunan kadar betasianin relative sedikit. Adanya penurunan kadar betasianin ini terjadi akibat rusaknya molekul betasianin.

Von Elbe dalam Vargas et al., (2010) menyatakan bahwa $\mathrm{pH}$ terlalu rendah atau terlalu tinggi akan menimbulkan ketidakstabilan struktur gugus kromofor, sehingga mempengaruhi intensitas warna merah pada senyawa betalain. Penurunan $\mathrm{pH}$ akan menyebabkan perubahan pigmen merah menjadi warna ungu, sedangkan kenaikan $\mathrm{pH}$ menyebabkan perubahan menjadi kuning kecokelatan. Selain itu kondisi penyimpanan yang tidak vakum serta suhu yang tidak konstan juga dapat mempengaruhi kadar betasianin. Dimana menurut Herbach et al., (2006) peningkatan $\mathrm{pH}$, intensitas cahaya, oksigen dan ion logam dapat mempengaruhi kestabilan betasianin.

\section{KESIMPULAN}

Kadar betasianin tertinggi terdapat dalam ekstrak buah kaktus (Opuntia elatior mill.) diperoleh menggunakan pelarut air. 
Kadar betasianin sangat dipengaruhi oleh paparan cahaya matahari selama penyimpanan. Kadar betasianin berkurang sebesar 66,86\% pada botol bening dan $47,28 \%$ pada botol cokelat selama 5 jam penyimpanan. Betasianin cenderung stabil pada kondisi $\mathrm{pH} 4,5$ dan 6 selama 3 hari penyimpanan.

\section{UCAPAN TERIMA KASIH}

Secara khusus peneliti mengucapkan terima kasih kepada Laboran Kimia FMIPA Universitas Tadulako.

\section{DAFTAR PUSTAKA}

Attoe, E.L. dan von Elbe, J.H. 1981, Photocemical degradation of Betanine and Selected Anthocyanins. Journal of Food Science, 46. 1934-1937.

Azeredo, H.M.C., 2006, Betalains: Properties, Source, Applications, and Stability - a Review, International Journal Food Science and Technology. 44:2365-2376.

Cai Y., Sun M., Corke H. 1998. Colourant Properties and Stability of Amaranthus betacyanin piments, Journal of Food Aglicultural and Food Chemistry. 46: 4491-4495.

Chauhan S.P., Sheth N.R., Rathod I.S., Suhagia B.N., Maradia R.B. 2013. Phytochemical Screening of Fruits of Opuntia elatior Mill. American Journal of Pharmatech Research, 3(2): 2249-3387.

Field L.D., Strenhel S., Kalman J.R. 2008. Organic Structures From Spectra, Fourth edition. England: John Wiley and Sons LTD.

Harborne J.B. 1987. Metode Fitokimia Penuntun Cara Modern Menganalisis Tumbuhan, Edisi II, diterjemahkan oleh Padmawinata K., Sudiro I., Bandung: ITB.
Hargis L.G. 1988. Analytical Chemistry: Principles And Technigues. New Jersey: Prentice Hall Inc.

Herbach K.M., Stinizing F.C., Carle R. 2006. Betalain stability and Degradation Structural and Chromatic Aspect, Journal of Food Sience. 71: 41-50.

Jackman R.L., Smith, J.L. 1996. Anthocyanin and Betalains, in Natural food colourants, pp 244-309, London: Blackie Academic and Professional.

Khuluk A.D., Widjarmoko S.B., Murtini E.S. 2007. Ekstraksi dan Stabilitas Betasianin Daun Darah (Althernathera dentate) Kajian Pelarut Etanol : Air dan Suhu Ekstraksi, Jurnal Teknologi Pertanian. 8(3).

Lim S.D., Yusof Y.A., Chin N.L., Talib R.A., Edjan J., Azis M.G. 2011. Effect of Extraction Parameters on the Yield of Betacianins from Pitaya Fruit (Hylocereus polyrhizus) Pulps. Food, Agriculture and Environment. 9(2): 158-162.

Moss B.W. 2002. Improving Quality, dalam Macdougall, D.B. (Ed) Color in Food. 145-175. New York: CRC Press LLC.

Reshmi S.K., Aravindhan K.M., Suganya P. 2012. Then Effect of Light, Temperature, $\mathrm{pH}$, on Stability of Betacyanin Pigments in Basella alba Fruit. Asian Journal of Pharmaceutical dan Clinical Research. 5(4): 107-110.

Rukmana R., Yuniarsih Y.O. 1998. Tanaman Hias Kaktus, Bandung: Kanisius.

Vargas F.D., Jimenez A.R., Lopez O.P. 2010. Natural Pigments: Carotenoids, Anthocyanins, and Betalains Characteristics, Biosynthesis, Processing, and Stability. Critical Reviews in Food Science and Nutrition, 40(3):173-289. 